\title{
PENGARUH DESKRIPSI PEKERJAAN TERHADAP KINERJA PEGAWAI NEGERI SIPIL PADA KANTOR CAMAT TEMBILAHAN
}

\section{THE EFFECT OF JOB DESCRIPTION ON CIVIL SERVANT'S PERFORMANCE IN TEMBILAHAN SUBDISTRICT OFFICE}

\author{
Meilisa Syelviani \\ Fakultas Ekonomi, Universitas Islam Indragiri \\ meilisasyelviani2@gmail.com
}

\begin{abstract}
Job description or work flows is an important thing that needed in every company or organization. The purpose of this study is to determine the effect of job description on civil servant's performance in Tembilahan sub-district office. Independent variable of this research is job description, and dependent variable is performance. Population of this research are 30 (thirty) Civil Servant's workers in Tembilahan sub-district office. Sampling technique used is total sampling or census. Data analysis used is linear regression. The result showed that there is significance influence between job description against civil servant's performance in Tembilahan Sub-district office with the number of adjusted $R$ square $72 \%$, means the other $28 \%$ of employee's performance influences by another factors.
\end{abstract}

Keywords: job descriptions, performance

\section{ABSTRAK}

Deskripsi pekerjaan atau uraian pekerjaan sangat diperlukan dalam setiap perusahaan maupun dalam organisasi. Tujuan penelitian ini adalah untuk mengetahui pengaruh deskripsi pekerjaan terhadap kinerja Pegawai Negeri Sipil pada kantor Camat Tembilahan Kota. Variabel bebas dalam penelitian ini adalah deskripsi pekerjaan, sedangkan variabel terikatnya adalah kinerja. Populasi dalam penelitian ini adalah pegawai kantor Camat Tembilahan yang berjumlah 30 orang. Metode pengumpulan data dilakukan dengan menggunakan teknik sampling jenuh atau sensus. Data diuji menggunakan regresi linear sederhana. Hasil penelitian menunjukkan terdapat pengaruh yang signifikan antara deskripsi kerja terhadap kinerja pegawai negeri sipil di kantor camat Tembilahan dengan nilai adjusted $R$ square $72 \%$ yang artinya sebanyak $28 \%$ kinerja pegawai dipengaruhi oleh faktor lain.

Kata Kunci: Deskripsi Pekerjaan, Kinerja

\section{PENDAHULUAN}

Setiap pekerjaan itu adalah sangat berlainan, karena setiap pekerjaan menuntut pengalaman dan pengetahuan yang berlainan pula. Yang menjadi tantangannya adalah manajemen harus mampu menganalisis tipe karyawan atau pegawai seperti apa yang dibutuhkan, manajemen perlu melihat apa yang dituntut dari setiap pekerjaan dalam organisasi maupun perusahaan melalui deskripsi pekerjaan yang terinci. Deskripsi pekerjaan tersebut bisa menjadi suatu rintangan apabila tidak akurat, tidak lengkap dan kadaluarsa. Penulisan dari deskripsi pekerjaan yang sempurna dapat menjadi aser dan dapat menggambarkan dengan 
jelas posisi dalam organisasi yang dapat memberikan pandangan operasional secara keseluruhan dan juga dapat menunjukan bahwa deskripsi pekerjaan telah dirancang dan dianalisis sebagai suatu bagian integral dari pelayanan organisasi. Mondy (2005) menyatakan bahwa Deskripsi pekerjaan harus dilaksanakan agar organisasi dapat mencapai tujuannya.

Deskripsi pekerjaan atau uraian pekerjaan sangat diperlukan dalam setiap perusahaan maupun dalam organisasi. Suatu organisasi mempunyai alasan mengapa harus ada, untuk apa diadakan dan sasaran apa yang harus dicapai. Ibarat navigator, deskripsi pekerjaan merupakan peta yang dijadikan sebagai yang menjunjukan arah, kemana harus belok, berapa kecepatan yang diperlukan dan seterusnya.Karena itu, suatu organisasi maupun perusahaan merumuskan visi, misi dan perencanaan yang kemudaian membentuk suatu struktur. Dari struktur inilah selanjutnya pekerjaan atau jabatan itu muncul. Setiap organisasi ataupun perusahaan memiliki tujuan atau visi misinya masing-msing yang ingin dicapainya. Salah satu pencapaian itu melalui deskripsi pekerjaan atau uraian pekerjaan. Seorang pemimpin harus mampu bekerja sama dengan pegawai, begitu juga sebaliknya pegawai juga harus cakap terhadap deskripsi pekerjaan (job description) yang telah diberikan kepadanya dengan penuh rasa tanggung jawab dan melaksanakan tugas dengan baik dan benar. Hasibuan (2005) Dengan adanya deskripsi pekerjaan tersebut akan membentuk kinerja pegawai yang handal dibidangnya masingmasing.

Wiwin (2012) dalam penelitiannya menjelaskan bahwa dengan adanya deskripsi pekerjaan diharapkam tugas-tugas yang diberikam pimpinan dapat dikerjakan tepat pada waktunya dan hasil yang baik dengan upaya menjelaskan tugas pokok dan fungsi masing-masing darisetiap klasifikasi jabatan untuk mengetahui dan memahami posisi masing-masing.

Menurut Hasibuan (2005), deskripsi pekerjaan (job description) adalah informasi tertulis yang menguraikan tugas dan tanggung jawab, kondisi pekerjaan, hubungan pekerjaan dan aspek-aspek pekerjaan pada suatu jabatan tertentu dalam organisasi. Deskripsi pekerjaan akan memberikan ketegasan dan standar tugas yang harus dicapai oleh seseorang yang memegang jabatan tersebut. Selain itu deskripsi pekerjaan juga dapat menjadi dasar untuk menetapkan spesifikasi pekerjaan dan evaluasi pekerjaan dalam memegang suatu jabatan. Deskripsi pekerjaan yang jelas dapat membantu pegawai dalam meningkatkan kinerja pegawai karena pegawai memiliki arah terhadap apa yang menjadi tugas pokok dan fungsinya dalam bekerja. Deskripsi pekerjaan yang kurang jelas akan mengakibatkan seorang pegawai itu kurang mengetahui tugas dan tanggung jawabnya. Hal ini yang dapat mengakibatkan pekerjaan menjadi tidak beres. Disinilah letak pentingnya peranan deskripsi pekrjaan dalam sebuah organisasi maupun perusahaan.

Hasibuan (2005), deskripsi pekerjaan harus jelas, persepsinya 
mudah dipahami serta menguraikan hal-hal seperti: identifikasi pekerjaan atau jabatan yaitu dengan memberikan nama jabatan; hubungan tugas dan tanggung jawab yaitu perincian tugas dan tanggung jawab secara nyata diuraikan terapisah agar jelas diketahui; rumusan pekerjaan hendaknya menunjukan hubungan antara pejabat dengan orang lain di dalam maupun di luar organisasi; standar wewenang dan pekerjaan yakni kewenangan dan prestasi yang harus dicapai oleh seorang pegawai harus jelas; syarat kerja harus diuraikan dengan jelas, ringkasan pekerjaan hendaknya menguraikan pekrajaan bentuk umum pekerjaan dengan hanya mencantumkan fungsi-fungsi dan aktivitas utamanya; serta penjelasan tentang jabatan dibawah dan diatasnya harus dijelaskan jabatan darimana si pegawai dipromosikan dan ke jabatan mana si pegawai akan dipromosikan. Tanpa deskripsi pekerjaan, organsasi hanya merupakan kelompok manusia yang kacau, tidak teratur dan tidak dapat mencapai tujuan yang diinginkan organsisasi.

Mondy (2005), induk kajian deskripsi pekrjaan adalah amalisis pekerjaan. Informasi yang diperoleh melalui analisis pekerjaan penting untuk penyusunan deskripsi pekerjaan dan spesifikasi pekerjaan. Deskripsi pekrejaan merupakan produk yang pertama dan langsung dari proses analisis pekerjaan berupa pernyataan yang akurat dan ringkas tentang apa yang diharapkan akan dilakasanakan oleh pegawai dalam melaksanakan pekerjaan yang menjadi tugas pokok dan fungsi nya dalam diri setiap pegawai yang memangku jabatan yang telah dimilikinya. Dengan adanya hal ini, merupakan suatu aktivitas dalam upaya menciptakan kualitas dari suatu pekerjaan dan kualitas dari kinerja total suatu organisasi maupun perusahaan. Sehingga deskripsi pekerjaan dapat memnerikan pen garuh terhadap kinerja pegawai. Menurut Hasibuan (2005), Kinerja adalah suatu hasil kerja yang dicapai oleh seseorang dalam melaksanakan tugas-tugas yang dibebankan kepadanya yang didasarkan atas kecakapan, pengalaman dan kesungguhan serta waktu.

Adapun tujuan penulisan ini dilakukan untuk memperoleh bukti empiris mengenai pengaruh deskripsi pekerjaan terhadap kinerja pegawai yang mana dapat dijadikan sebagai bahan evaluasi terhadap deskripsi pekerjaan. Objek penelitian adalah kantor Camat Tembilahan Kota. Sebagaimana kantor Camat Tembilahan Kota yang merupakan kepala pemerintahan di wilayah kecamatan Tembilahanyang berada dibawah dan bertanggung jawab kepada Kepala Daerah /Bupati Indragiri Hilir. Camat Tembilahan kota menerima pelimpahan dari Kepala Daerah/ Bupati Indragiri Hilir melaksanakan kegiatan penyelenggaraan pemerintah, penyelenggaraan pembangunan dan pembinaan sosial kemasyarakatan dalam wilayah Kecamatan Tembilahan. Sesuai dengan penjelasan tersebut, maka pemerintah berupaya membentuk sebuah konsep mengenai deskripsi pekerjaan secara jelas yang termuat dalam Pedoman Analisis Jabatan 
berdasarkan Keputusan

Menteri Pemberdayaan Aparatur Negara (KEP/29/M.PAN/6/2005)

\section{Tabel 1. Uraian Jabatan Pegawai Negeri Sipil yang ada di kantor Camat Tembilahan Kota}

\begin{tabular}{|c|c|c|c|c|c|}
\hline \multirow{2}{*}{ No } & \multirow{2}{*}{ Jabatan } & \multirow{2}{*}{ Pangkat } & \multirow{2}{*}{ Esselon } & \multicolumn{2}{|c|}{ Jumlah } \\
\hline & & & & $\mathrm{Ka}$ & Staf \\
\hline 1. & Camat & Pembina (IV/a) & IIIa & 1 & - \\
\hline 2. & Sekretaris Camat & Penata Tk.I (III/d) & IIIlb & 1 & - \\
\hline \multirow[t]{2}{*}{3.} & Seksi Umum & Penata Tk.I (III/d) & IVa & 1 & - \\
\hline & Staf Umum & Pengatur II/c & - & - & 1 \\
\hline \multirow[t]{2}{*}{4.} & Seksi Tata Pemerintahan & Penata III/c & IVa & 1 & - \\
\hline & Staf Tata Pemerintahan & Penata Tk.I (II/d) & - & - & 1 \\
\hline \multirow[t]{2}{*}{5.} & Seksi PMD & Penata Tk.I (III/b) & IVa & 1 & - \\
\hline & Staf PMD & Pengatur II/c & - & - & 1 \\
\hline \multirow[t]{2}{*}{6.} & Seksi Kesejahteraan Sosial & Penata III/c & IVa & 1 & - \\
\hline & Staf Kesejahteraan Sosial & Pengatur Tk.I(IId) & - & - & 1 \\
\hline \multirow[t]{2}{*}{7.} & Seksi Trantib & Penata III/b & IVa & 1 & - \\
\hline & Staf Trantib & Pengatur II/c & - & - & 11 \\
\hline \multirow[t]{3}{*}{8.} & Sub Bagian Administrasi & Penda Tk.I (III/b) & $\mathrm{IVb}$ & 1 & 1 \\
\hline & Staff Administrasi & Pengda (II/a) & - & - & 1 \\
\hline & Staff Administrasi & Pengatur (II/c) & - & - & 1 \\
\hline \multirow[t]{3}{*}{9.} & Sub Bagian Keuangan & Penata (III/c) & $\mathrm{IVb}$ & 1 & - \\
\hline & Staf Keuangan & Pengatur Tk.I(IId) & - & - & 2 \\
\hline & Staf Keuangan & Pengatur IIc & - & - & 1 \\
\hline 10. & Seksi Perencanaan & Penata III/c & $\mathrm{IVb}$ & 1 & - \\
\hline \multicolumn{3}{|c|}{ Jumlah } & & \multicolumn{2}{|c|}{30} \\
\hline
\end{tabular}

Sumber : Kantor Camat Tembilahan Kota

yaitu berisi nama jabatan, ringkasan tugas, hasil kerja, bahan kerja, peralatan kerja, rincian tugas, kondisitempat kerja, upaya fisik, resiko bahaya, syarat jabatan. Yang mana dengan adanya deskiripsi pekerjaan tersebut dapat membantu pegawai menghindari adanya kebingungan dan memberikan pemahaman bagi pegawai dalam melaksanakan pekerjaan, dapat menghindari tumpang tindih tanggung jawab, mempermudah prosedur rekrutmen, seleksi, pelatihan dan berbagai aktivitas sumber daya manusia lainnya. Sistem kerja berdasarkan Struktur Organisasi dan Tata kerja (SOT) pada No.32 Tahun 2008 tentang Organisasi dan Tata Kerja Kecamatan dan Kelurahan Kabupaten Indragiri yang berdasarkan struktur organisasi dengan susunan sebagai berikut:
Dalam

realisasinya, deskripsi pekerjaan masih minim pada kantor Camat Tembilahan Kota. Masih banyak pegawai yang belum bisa menyelesaikan tugasnya sendiri karena terbatasnya skill yang dimiliki, terlebih lagi pendiskripsiaan pekerjaan belum dilaksanakan dengan benar. Skill yang kurang sesuai dengan jabatan akan mengakibatkan terbengkalainya tugas yang ada. Permasalahan yang lainnya, dalam pelaksanaan operasional pegawai yang dipengaruhi oleh banyaknya jumlah seksi pekerjaan dari struktur organisasi yang ada sedangkan jumlah pegawainya kurang dari seksi jabatan yang ada, sehingga dalam pelaksanaan tugasnya terganggu dan mengkibatkan adanya pekerjaan yang lamban dalam melakukan suatu pelayanan masyarakat. Selain itu, kinerja pegawai juga dipengaruhi oleh 
kurangnya alat dalam pelaksanaan serta adanya pegawai yang kurang bisa dalam menggunakan alatyang dapat mempangaruhi kinerja pegawai tersebut. Oleh karena itu, pendiskripsian pekerjaan yang tepat akan membuat setiap pegawai mampu menyelesaikan tugasnya masing-masing. Hal ini lah yang akan mendukung tercapainya peningkatan kinerja pergawai, karena pegawai telah memahami apa yang seharusnya pegawai kerjakan dengan didukung adanya kejelasan dari deskrispsi pekerjaan yang diberikan.

Menurut Hasibuan (2005), deskripsi pekerjaan (job description) adalah informasi tertulis yang menguraikan tugas dan tanggung jawab, kondisi pekerjaan, hubungan pekerjaan dan aspek-aspek pekerjaan pada suatu jabatan tertentu dalam organsisasi. Deskripsi pekerjaan dakan memberikan ketegasan dan standar tugas yang harus dicapai oleh seseorang yang memegang jabatan tersebut. Handoko (2008), deskripsi pekerjaan adalah suatu pernyataan tertulis yang menguraikan fungsi, tugas-tugas, tanggung jawab, wewenang, kondisi kerja dan aspekaspek pekerjaan tertentu lainnya. Semua deskripsi mempunyai bentuk (style) yang sama meskipun diantara organisasi-organisasi yang berbeda bentuk dan isi deskripsi pekerjaan bisa bervariasi. Sedangkan Dessler (2010) mengatakanbahwa deskripsi pekerjaan adalah pernyataan tertulis apa yang sebenarnya yang harus dilakukan oleh pekerja, bagaimana orang itu melakukannya, dan bagaimana kondisi kerjanya. Deskripsi pekerjaan harus menggambarkan posisi pekerjaan dengan baik sehingga kewaajiban pekerjaan tersebut jelas tanpa mengacu pada deskripsi pekerjaan lainnya.

Menurut Hasibuan (2005), kinerja (prestasi kerja) adalah suatu hasil kerja yang dicapai seseorang dalam melaksanakan tugas-tugas yang dibebankan kepadanya yang didasarkan atas kecakapan, pengalaman dn kesungguhan derta waktu. Menurut Handoko (2008), kinerja atau penilaian prestasi kerja merupakan proses melalui mana organisasi mengevaluasi atau menilai prestasi kerja pegawai. Penilaian yang da pada dasarnya merupakan penilain yang sitematik terhadap pempilan kerja karyawan terhadap taraf potensi pegawai dalam upaya pengembangan diri untuk kepentingan organisasi maupun perusahaan.

Simanjuntak

(2005), menyatakan kinerja dalah tingkatan pencapaian hasil atas pelaksanaan tugas tertentu dalam rangka mewujudkan pencapaian hasil untuk mencapai tujuan. Lanjutnya, manfaat dari penilaian kinerja adalah untuk peningkatan kinerja, pengembangan sumber daya manusia, pemberian kompensasi, program peningkatan produktivitas, program kepegawaian, menghindari perlakuan deskriminasi. Objek penilaian kinerja yaitu sifat yang dinilai dari karyawan dan sifat yang dinilai dari orang yang memegang posisi pimpinan. Menurut Mathis dan Jackson (2006), kinerja atau penilaian kinerja (performance apprasial) adalah proses mengevaluasi seberapa baik pegawai melakkukan pekerjaan mereka jika dibandingkan dengan seperangkat standar, dan 
mengkomunikasikan informasi tersebut kepada pegawai. Penilaian kinerja juga disebut pemeringkatan pegawai, evaluasi pegawai, tujuan kerja, evaliasi kinerja dan penilaian hasil.

Wiwin (2010), dalam penelitian terdahulu mengatakan bahwa dalam suatu orgaisasi deskripsi pekerjaan sangat perlu disusun agar sumber daya yang ada dapat difungsikan sebagaimana mestinya, sehingga orang-orang yang terlibat didalamnya bisa lebih mengerti mengenai tugas, wewenang maupun tanggung jawab dari jabatannya. Berdasarkan kesimpulan bahwa deskripsi pekerjaan memiliki hubungan terhadap kinerja pekerjaan karyawan.

Hasibuan (2007), menyatakan bahwa adanya pengaruh deskripsi pekerjaan terhadap pekerjaan, yakni apabila deskripsi pekerjaan kurang jelas akan mengakibatkan seorang karyawan kurang mengetahui tugas dan tanggung jawabnya pada pekerjaan itu, mengakibatkan pekerjaan tidak tercapai dengan baik yang akan berpengaruh terhadap kinerja karyawan. Proses penilaian kinerja berdasarkan pada analisis pekerjaan atau analisis jabatan. Tahap ini merupakan tahap yang cukup penting yang merupakan tahap mendasar dalam penilaian kinerja, karena analisis jabatan dipergunakan untuk beberapa kegiatan dalam proses penilaian kinerja. Hasil dari analisis jabatan ini digunakan sebagai dasar penyusunan deskripsi pekerjaan, dimana dalam deskripsi pekerjaan ini disebutkan dasar-dasar penilaian yaitu jenis-jenis pekerjaan yang harus dikerjakan dan spesifikasi taau kebutuhan khusus yang menunjang pekerjaan tertentu. Inti dari tahap ini adalah apabila akan melaksanakan penilaian kinerja, maka sebelumnya harus dinyatakan dengan jelas hal-hal berikut : jenisjenis pekerjaan, tanggung jawab yang dimiliki, kondisi kerja, kegiatan yang harus dilakukan. Penilaian kinerja merupakan sebuah sistem atau sekumpulan kegiatan yang terkait dengan aktivitas kepegawaian lainnya. Penilaian kinerja tidak dapat berdiri sendiri, sehingga dalam pelaksanaannya, penilaian kinerja juga terkait dengan kegiatan lain. Keterkaitan proses penilaian kinerja juga terkait dengan kegiatan lain.

Hasibuan (2005), menjelaskan bahwa analisis pekerjaan memberikan informasi yang digunakan untuk membuat deskripsi pekerjaan dan spesifikasi pekerjaan. Berdasarkan tinjauan landasan teori dan penelitian terdahulu, maka dapat disusun suatu kerangka pemikiran.Variabel x yaitu deskripsi pekerjaan dan variabel y yaitu kinerja.

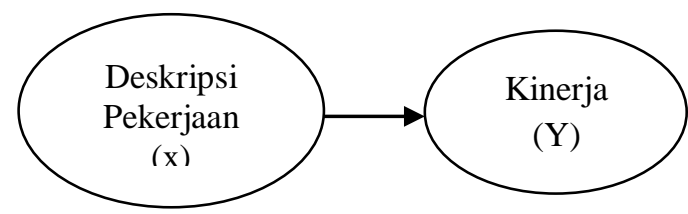

Gambar 1 Kerangka Pemikiran

\section{METODE PENELITIAN \\ Objek Penelitian}

Penelitian ini dilakukan pada Kantor Camat Tembilahan Kota yang beralamat di Jalan Veteran Tembilahan, Kabupaten Indragiri Hilir, Riau. 


\section{Sumber dan Jenis Data}

Sumber data yang digunakan berupa data primer dan data sekunder dati kantor Camat Tembilahan Kota. Data primer berupa data yang berasal dari sumber asli atau pertama yang berupa angket yang disebarkan kepada responden dan juga sumber data yang akurat yang diperoleh dari kantor Camat Tembilahan Kota.Data sekunder berupa data yang sudah tersedia sehingga kita tinggal mencaari da mengumpulkannya. Data sekunder ini berupa situs internet, pustaka, hasil penelitian terdahulu dan lain sebagainya.

Sedangkan jenis data yang digunakan berupa data kualitataif dan data kuantitatif baik itu berupa data yang bersifat angka maupun buka bersifat angka. Data kuaitatif merujuk pada kualitas objek penelitian yaitu ukuran data berupa non-angka yang diperoleh berupa data yang bersumber dari pihak instansi yang berupa kalimat serta keterangan. Data kuantitatif berupa data yang didominasi oleh angka yang menyangkut realisasi penelitian di Kantor Camat Tembilahan Kota.

\section{Populasi dan Sampel}

Populasi berupa wilayah generalisasi yangt terdiri atas objek/subjek yang mempunyai kuantitas dan karakteristik tertentu yang ditetapkan oleh peneliti untuk dipelajari kemudian diambil kesimpulan. Yang menjadi populasi kantor Camat Tembilahan Kota adalah seluruh pegawai kantor Camat Tembilahan Kota yang berjumlah 30 (tiga puluh) orang. Namun yang dijadikan Sampel dengan nilai minilal adalah 30 (tiga puluh) orang sampel.

Variabel Penelitian

Variabel $\mathrm{x}, \quad$ Deskripsi pekerjaan, Hasibuan (2005) yaitu informasi tertulis yang menguraikan tugas dan tanggung jawab, kondisi pekerjaan, hubungan pekerjaan dan aspek-aspek pekerjaan pada suatu jabatan tertentu dalam organisasi. Indikator terdiri dari kondisi pekerjaan, jabatan, tanggung jawab dan hubungan kerja.

Variabel Y, kinerja, Hasibuan (2005) yaitu suatu hasil kerja yang dicapai seseorang dalam melaksanakan tugas-tugas yang dibebankan kepadanya didasarkan atas kecakapan, pengalaman, kesungguhan serta waktu. Indikator terdiri dari waktu, kesungguhan, pengalaman dan kecakapan.

\section{Uji Pendahuluan}

\section{Uji Instrumen \\ a. Uji Validitas}

Validitas merupakan suatu ukuran yang menunjukkan tingkattingkat kevalidan atau kesahihan suatu instrumen. Suatu instrumen yang valid atau sahih mempunyai validitas tinggi. Sebaliknya, instrumen yang kurang valid berarti memiliki vailiditas rendah. Sebuah instrumen dikatakan valid jika mampu mengukur yang diinginkan, serta dapat mengungkapkan data dari variabel yang diteliti secara tepat. Tinggi rendahnya vailiditas instrumen yang menunjukkan sejauh mana data yang dikumpulkan tidak menyimpang dari gambaran tentang variabel yang dimaksud, Arikunto (2002). Jika nilai $r_{\text {hitung }} \geq r_{\text {tabel }}$ maka instrumen tersebut dapat dikatakan valid dan apabila nilai $r_{\text {hitung }} \leq r_{\text {tabel }}$ 
maka instrumen tersebut dikatakan tidak valid.

\section{b. Uji Reliabelitas}

Reliabilitas

merupakan

suatuinstrumen yang cukup dapat dipercaya unruk digunakan sebagai alat pengumpul data karena instrumen tersebut sudah baik, Arikunto (2002). Uji reliabelitas dalam penelitian ini dilakukan dengan menggunakan rumus Cornbach Alpha.

\section{Uji Hipotesis}

Uji Hipotesis bertujuan untuk mengetahui signifikan atau tidaknya pengaruh variabel independen terhadap variabel dependen. Untuk lebih jelas berikut dibahas setiap pengujian hipotesis yang digunakan dalam penelitian ini:

\section{a. Koefisien Determinasi $\left(\mathbf{R}^{2}\right)$}

Koefisien determinasi $\left(\mathrm{R}^{2}\right)$ di gunakan untuk mengukur seberapa jauh kemampuan model dalam menerangkan variasi variabel dependen. Nilai koefisien determinasi adalah antara 0 dan 1 . Nilai $\mathrm{R}^{2}$ yang kecil bararti variabel dependen sangat terbatas, Ghozali (2005).

\section{b. Uji Parsial (t)}

Uji $t$ digunakan untuk mengetahui apakah variabel independen secaara parsial berpengaruh secara signifikan terhadap variabel dependen dengan menggunakantingkat keyakinan 95\% $(\alpha=0.05)$. Uji ini dilakukan sekaligus untuk melihat koefisien regresi secara individual variabel penelitian, Ghozali (2005).

\section{c. Uji Simultan (F)}

Uji ini digunakan untuk menegtahui apakah variabel independen $(\mathrm{x})$, berpengaruh secara signifikan terhadap variabel dependen (Y). $F_{\text {hitung dapat dicari }}$ dengan rumus sebagai berikut:

Tahap-tahap yangdilakukan untuk menguji dari uji $\mathrm{F}$ adalah sebagai berikut:

a. Merumuskan hipotesis

Ho : tidak ada pengaruh secara signifikan dan positif antara $X$ terhadap Y

$\mathrm{Ha}$ : ada pengaruh secara signifikan dan positif antara $\mathrm{X}$ terhadap Y

b. Menentukan tingkat signifikan

Tingkat signifikan menggunakan $\mathrm{a}=5 \%$

Ho diterima jika $0,05<\mathrm{sig}$

Ho ditolak jika 0,05> sig

c. Menentukan nilai $F_{\text {hitung }}$

Berdasarkan hasil $F_{\text {hitung }}$ dari SPSS

d. Menentukan $\mathrm{F}_{\text {tabel }}$

Berdasarkan hasil $\mathrm{F}_{\text {tabel }}$ dari SPSS

d. Kriteria pengujian

- Ho diterima jika $F_{\text {hitung }}<F_{\text {tabel }}$

- Ha ditolak jika $F_{\text {hitung }}>F_{\text {tabel }}$

e. Membandingkan $F_{\text {hitung }}$ dengan $F_{\text {tabel }}$

f. Kesimpulan

\section{Analisa Korelasi}

Analisis yang digunakan untuk mengukur kekuatan antara dua variabel. Untuk menafsirkan hal tersebut, Sarwono (2006) digunakan kriteria sebagai berikut :

1. $0-0.25$ : Korelasi sangat lemah (dianggap tidak ada)

2. > $0.25-0.5$ : Korelasi cukup

3. > 0.5-0.75: Korelasi kuat dan searah

4. > $0.75-1$ : Korelasi sangat kuat dan searah

\section{Analisis Data}

Dalam penelitian ini, metode yang duganakan untuk menganalisis bagaimana pengaruh deskripsi pekerjaan terhadap kinerja Pegawai 
Negeri Sipil pada kantor Camat Tembilahan Kota, menggunakan rumusan analisis regresi yaitu analisis regresi linier sederhana dengan persamaan: $\mathbf{Y}=\mathbf{a}+\boldsymbol{\beta} \mathbf{x}_{\mathbf{1}}$

Keterangan :

$\mathrm{Y}=$ kinerja

$\mathrm{a}=$ konstanta

$\beta \mathrm{X}_{1}=$ koefisien regresi (deskripsi pekerjaan)

\section{HASIL DAN PEMBAHASAN}

\section{Uji Instrumen}

a. Uji Validitas

Tabel 2 Hasil Output Validitas Variabel

\begin{tabular}{|c|c|c|c|c|}
\hline \multirow{2}{*}{ Variabel } & \multirow{2}{*}{ Indikator } & \multirow{2}{*}{ Item } & \multicolumn{2}{|c|}{ Komponen } \\
\hline & & & 1 & 2 \\
\hline \multirow{4}{*}{$\begin{array}{l}\text { Deskripsi } \\
\text { pekerjaan } \\
\text { (X) }\end{array}$} & $\begin{array}{l}\text { Kondisi } \\
\text { pekerjaan }\end{array}$ & $\begin{array}{l}\text { Pertanyaan } 1 \\
\text { Pertanyaan } 2\end{array}$ & $\begin{array}{l}.725^{* * *} \\
.749^{* *}\end{array}$ & \\
\hline & Jabatan & $\begin{array}{l}\text { Pertanyaan } 1 \\
\text { Pertanyaan } 2\end{array}$ & $\begin{array}{l}.633^{* * *} \\
.757^{* * *}\end{array}$ & \\
\hline & $\begin{array}{l}\text { Tanggung } \\
\text { jawab }\end{array}$ & $\begin{array}{l}\text { Pertanyaan } 1 \\
\text { Pertanyaan } 2\end{array}$ & $\begin{array}{l}.775^{* *} \\
.377^{*}\end{array}$ & \\
\hline & $\begin{array}{l}\text { Kondisi } \\
\text { pekerjaan }\end{array}$ & $\begin{array}{l}\text { Pertanyaan } 1 \\
\text { Pertanyaan } 2\end{array}$ & $\begin{array}{l}.485^{* *} \\
.538^{* * *}\end{array}$ & \\
\hline \multirow[t]{4}{*}{$\begin{array}{l}\text { Kinerja } \\
\text { (Y) }\end{array}$} & Waktu & $\begin{array}{l}\text { Pertanyaan } 1 \\
\text { Pertanyaan } 2\end{array}$ & & $\begin{array}{l}.503^{* *} \\
.799^{* *}\end{array}$ \\
\hline & Kesungguhan & $\begin{array}{l}\text { Pertanyaan } 1 \\
\text { Pertanyaan } 2\end{array}$ & & $\begin{array}{l}.645^{* *} \\
.810^{*}\end{array}$ \\
\hline & Pengalaman & $\begin{array}{l}\text { Pertanyaan } 1 \\
\text { Pertanyaan } 2\end{array}$ & & $\begin{array}{l}.692^{* *} \\
.475^{\text {** }}\end{array}$ \\
\hline & Kecakapan & $\begin{array}{l}\text { Pertanyaan } 1 \\
\text { Pertanyaan } 2\end{array}$ & & $\begin{array}{l}.496^{* * *} \\
.452^{*}\end{array}$ \\
\hline
\end{tabular}

Sumber : Data Olahan

Dari hasil pengujian variabel bebas berupa deskripsi pekerjaan dan variabel terikat berupa kinerj, maka berdasarkan hasil penelitian diperoleh validitas instrument penelitian (kuesioner) pada variabel deskripsi pekerjaan dan kinerja dengan masing-masing pertanyaan output diatas dapat diketahui bahwa $r_{\text {hitung }} \geq r_{\text {tabel }}$, yang mana $r_{\text {tabel }}$ dari 30 responden adalah 0.361 pada signifikan $5 \%$. Sehingga keseluruhan dari instrument penelitian tersebut dinyatakan valid.

\section{b. Uji Realibilitas}

Uji validitas dan reabilitas untuk menguji setiap indikator pada variabel telah valid (sahih) dan reliable (andal).

Tabel 3 Hasil Output Realibilitas Variabel

\begin{tabular}{lccc}
\hline Variabel & Item & $\begin{array}{c}\text { Koefisien } \\
\text { Cronbach } \\
\text { Alpha }\end{array}$ & Keterangan \\
\hline $\begin{array}{l}\text { Deskripsi } \\
\text { pekerjaan }\end{array}$ & 8 & .795 & Reliabel \\
\hline
\end{tabular}

(X)

$\begin{array}{llll}\text { Kinerja } & 8 & .765 & \text { Reliabel }\end{array}$
(Y)

Sumber : Data Olahan

Dari hasil penelitian dengan menggunakan variabel bebas berupa deskripsi pekrjaan dan variabel terikat berupa kinerja maka diperoleh hasil dari uji realibilitas didapat nilai Cronbach Alpha pada deskripsi pekerjaan sebesar 0.795 , dan nilai Alpha sebesar 0.765 pada kinerja, sedangkan $\mathrm{r}$ tabel dengan taraf signifikan 5\% adalah 0.361 . Maka dapat disimpulkan bahwa masing-masing instrumen penelitian tersebut reliabel.

\section{Analisa Regresi Linier Sederhana}

Untuk menganalisa pengaruh deskripsi pekerjaan terhadap kinerja Pegawai Negeri Sipil maka dilakukan analisa regresi linier sederhana, guna melihat pengaruh antara variabel bebas (X) dan variabel terikat (Y) dapat dijelaskan pada tabel berikut :

Tabel 4 Data Hasil Analisis Regresi

\begin{tabular}{cccccc}
\hline \multicolumn{7}{c}{ Coefficients $^{\mathbf{a}}$} \\
\hline & $\begin{array}{c}\text { Unstandardized } \\
\text { Coefficients }\end{array}$ & $\begin{array}{l}\text { Standardized } \\
\text { Coefficients }\end{array}$ & & \\
\cline { 2 - 5 } Model & $\mathrm{B}$ & Std. Error & Beta & $\mathrm{t}$ & Sig. \\
\hline 1 (Constant) & 7.799 & 2.384 & & 3.271 & .003 \\
\hline $\mathrm{X}$ & .759 & .087 & .854 & 8.698 & .000 \\
\hline
\end{tabular}




\begin{tabular}{|c|c|c|c|c|c|}
\hline \multicolumn{6}{|c|}{ Coefficients $^{a}$} \\
\hline \multirow[b]{2}{*}{ Model } & \multicolumn{2}{|c|}{$\begin{array}{l}\text { Unstandardized } \\
\text { Coefficients }\end{array}$} & \multirow{2}{*}{$\begin{array}{c}\begin{array}{c}\text { Standardized } \\
\text { Coefficients }\end{array} \\
\text { Beta }\end{array}$} & \multirow[b]{2}{*}{$\mathrm{t}$} & \multirow[b]{2}{*}{ Sig. } \\
\hline & B & Std. Error & & & \\
\hline 1 (Constant) & 7.799 & 2.384 & & 3.271 & .003 \\
\hline $\mathrm{X}$ & .759 & .087 & .854 & 8.698 & .000 \\
\hline \multicolumn{5}{|c|}{ a. Dependent Variable: y } & \\
\hline
\end{tabular}

Berdasarkan dari tabel diatas, persamaan regresi yang dihasilkan berikut :

$\mathrm{Y}=\mathrm{a}+\mathrm{bx}$

$Y=7.799+0.759 x$

Dari persamaan diatas dapat dijelaskan sebagai berikut:

a. Konstanta $=7.799$ artinya apabila instansi tidak melakukan deskripsi pekerjaan ataupun asalasalan, maka kinerja pegawai yang dihasilkan akan tetap sebesar 7.799.

b. Koefisien regresi $\mathrm{X}$ (deskripsi pekerjaan) $=0.759$ artinya apabila terdapat peningkatan variabel deskripsi pekerjaan sebesar satu satuan sementara variabel independen lainnya tetap, maka kinerja akan mengalami peningkatan sebesar 0.759 .

\section{Analisis Korelasi}

Analisis korelasi digunakan untuk mengukur kekuatan antara variabel. Untuk melihat hubungan deskripsi pekerjaan terhadap kinerja secara gabungan, digunakan analisis korelasi, maka akan dijelaskan pada hasil perhitungan model summary dibawah ini:

Tabel 5 Output Regresi Model Sumary

Model Summary

\begin{tabular}{ccccc}
\hline Model & $\mathrm{R}$ & R Square & $\begin{array}{c}\text { Adjusted R } \\
\text { Square }\end{array}$ & $\begin{array}{c}\text { Std. Error of } \\
\text { the Estimate }\end{array}$ \\
\hline 1 & $.854 \mathrm{a}$ & .730 & .720 & 2.33844 \\
\hline a. Predictors: (Constant), $\mathrm{x}$ & \\
\hline \multicolumn{5}{c}{ Sumber $:$ Data Olahan, }
\end{tabular}

Dari hasil perhitungan, didapatkan angka korelasi antara deskripsi pekerjaan dengan kinerja sebesar 0.730, artinya hubungan diantara variabel deskripsi pekerjaan dengan kinerja tersebut adalah kuat dan searah. Untuk menafsirkan hal tersebut menurut Sarwono (2006) digunakan kriteria sebagai berikut :
a. $0-0.25=$ Korelasi sangat lemah (dianggap tidak ada)
b. $>0.25-0.5=$ Korelasi cukup
c. $>0.5-0.75=$ Korelasi kuat dan searah
d. $>0.75-1=$ Korelasi sangat kuat dan searah
Korelasi positif menunjukkan bahwa hubungan antara deskripsi pekerjaan dengan kinerja kuat dan searah. Artinya jika deskripsi pekerjaan dilaksanakan dan ditingkatkan maka kinerja akan meningkat.

\section{Pengujian Hipotesis}

a. Uji Koefisien Determinasi

Tabel 8 : Output Regresi Model Summary

\begin{tabular}{llrrrr}
\hline \multicolumn{5}{c}{ Model Summary } \\
\hline & & & Adjusted & Std. Error of \\
Model & $\mathrm{R}$ & R Square & R Square & the Estimate \\
\hline 1 & $.854 \mathrm{a}$ & .730 & .720 & 2.33844 \\
\hline
\end{tabular}

a. Predictors: (Constant), $\mathrm{x}$

Sumber : Data Olahan

Hasil uji dari koeisien determinasi dapat dilihat dalam tabel 20. Pada tabel 20 menunjukan bahwa, nilai adjuster $\mathrm{R}^{2} 0.730$ atau $73.0 \%$. Hal ini berarti, perubahan kinerja dipengaruhi oleh deskripsi pekerjaan sebesar $73.0 \%$ dan sisanya $27 \%$ dipengaruhi faktor lain selain dari deskripsi pekerjaan. 


\section{b. Uji Statistik t}

Untuk menguji hipotesis selanjutnya adalah dengan uji statistik t. Uji ini digunakan untuk mengetahui pengaruh deskripsi pekerjaan terhadap kinerja secara parsial dapat dilihat pada tabel berikut:

Tabel 9: Output Regresi (coefficient)

\begin{tabular}{|c|c|c|c|c|c|}
\hline \multicolumn{6}{|c|}{ Coefficients $^{\mathrm{a}}$} \\
\hline \multirow[b]{2}{*}{ Model } & \multicolumn{2}{|c|}{$\begin{array}{l}\text { Unstandardize } \\
\text { d Coefficients }\end{array}$} & $\begin{array}{l}\text { Standardized } \\
\text { Coefficients }\end{array}$ & \multirow[b]{2}{*}{$\mathrm{t}$} & \multirow[b]{2}{*}{ Sig. } \\
\hline & B & $\begin{array}{l}\text { Std. } \\
\text { Error }\end{array}$ & Beta & & \\
\hline 1 (Constant) & 3.751 & 1.028 & & 3.648 & .001 \\
\hline $\begin{array}{l}\text { deskripsi } \\
\text { pekerjaan }\end{array}$ & .898 & .040 & .974 & 22.686 & .000 \\
\hline a. Dependent & Variable & e: kinerja & & & \\
\hline
\end{tabular}

Hasil analisis terdapat nilai sig 0.000 , artinya nilai sig lebih kecil dari nilai probabilitas 0.05 , atau nilai $0.000<0.05$, maka $\mathrm{Ha}$ diterima dan Ho ditolak. Variabel deskripsi pekerjaan mempunyai $\mathrm{t}$ hitung yakni 8.698 dengan $t$ tabel 2.048. Jadi $t_{\text {hitung }}$ deskripsi pekerjaan $8.698>\mathrm{t}$ tabel 2.048. Hal tersebut membuktikan bahwa variabel deskripsi pekerjaan (X) berpengaruh secara parsial terhadap kinerja.

\section{c. Uji Statistik F}

Uji hipotesis selanjutnya yaitu dengan uji $\operatorname{simultan}(\mathrm{F})$. Uji $\mathrm{F}$ statistik digunakan untuk melihat apakah variabel bebas yang dimasukkan dalam model regresi mempunyai pengaruh terhadap variabel terikat. Hasil perhitungannya dapat dilihat pada tabel berikut:
Tabel 10 : Output Regresi Model Anova

\begin{tabular}{lccccc}
\hline \multicolumn{6}{c}{ ANOVA $^{\text {b }}$} \\
\hline $\begin{array}{c}\text { Sum of } \\
\text { Model }\end{array}$ & $\begin{array}{c}\text { Mean } \\
\text { Squares }\end{array}$ & df & Square & F & Sig. \\
\hline 1 Regression & 413.688 & 1 & 413.688 & 75.652 & $.000 \mathrm{a}$ \\
\cline { 2 - 6 } & Residual & 153.112 & 28 & 5.468 & \\
\hline Total & 566.800 & 29 & & \\
\hline a. Predictors: (Constant), $\mathrm{x}$ \\
\hline b. Dependent Variable: $\mathrm{y}$ \\
\hline Sumber: Data Olahan
\end{tabular}

Pengujian hipotesis mengenai deskripsi pekerjaan secara simultan pada tabel diatas diperoleh nilai signifikannya $(0.000 \mathrm{a})<0,05$ dimana $F_{\text {hitung }}$ sebesar $75.652>F_{\text {tabel }}$ sebesar 3.328 maka Ho ditolak dan Ha diterima, hal ini berarti variabel deskripsi pekerjaan secara bersamasama berpengaruh terhadap kinerja.

Dari hasil perhitungan dengan menggunakan regresi linear, terlihat bahwa koefisien regresi deskripsi pekerjaan (X) bertanda positif, berarti deskripsi pekerjaan mempunyai pengaruh yang positif terhadap kinerja. Besarnya nilai koefisien regresi adalah 0.759 ini dapat diartikan jika deskripsi pekerjaan (X) meningkat $1 \%$, maka besarnya kinerja akan meningkat sebesar 0.759, jika pengaruh variabel lainnya dianggap konstan.

Berdasarkan hasil penelitian, variabel deskripsi pekerjaan merupakan variabel yang mempengaruhi kinerja Pegawai Negeri Sipil pada kantor Camat Tembilahan Kota secara parsial maupun simultan. Yang mana hal tersebut menerangkan bahwa deskripsi pekerjaan berpengaruh positif dan pengaruh sangat kuat untuk meningkatkan kinerja. 


\section{PENUTUP \\ Kesimpulan}

Penelitian ini bertujuan

untuk mengetahui pengaruh

Deskripsi Pekerjaan terhadap

kinerja Pegawai Negeri Sipil pada kantor Camat Tembilahan Kota. Adapun kesimpulan yang dapat ditarik dari hasil penelitian yang telah dilakukan antara lain :

Deskripsi Pekerjaan memiliki pengaruh yang signifikan terhadap kinerja Pegawai Negeri Sipil pada kantor Camat Tembilahan Kota. Dalam penelitian ini Deskripsi Pekerjaan memiliki pengaruh yang positif sehingga apabila variabel Deskripsi Pekerjaan meningkat maka akan meningkat pula kinerja Pegawai Negeri Sipil pada kantor Camat Tembilahan Kota. Kemudian dari hasil penelitian menunjukkan bahwa deskripsi pekerjaan mempengaruhi kinerja Pegawai Negeri Sipil pada kantor Camat Tembilahan Kota.

\section{Saran}

Berdasarkan kesimpulan yang diperoleh dalam penelitian ini, maka diajukan saran-saran sebagai berikut :

Untuk variabel deskripsi pekerjaan hendaknya dideskripsikan lagi lebih jelas agar pegawai paham akan tugas pokok dan fungsinya masingmasing, dengan adanya pengawasan yang cukup ketat dari pimpinan dan kesepakatan yang diadakan oleh atasan terhadap deskripsi pekerjaan yang jelas dan terarah akan membuat kinerja pegawai semakin meningkat.

Untuk variabel kinerja, suatu instansi harus memperhatikan kondisi kerja pegawai, dengan hal tersebut hasil kerja dapat terus meningkat. Sehingga deskripsi pekerjaan dan kinerja perlu ditingkatkan untuk mensukseskan suau organisasi maupuninstansi dimasa mendatang.

Penelitian ini hanya diteliti mengenai variabel Deskripsi Pekerjaan sehingga perlu dilakukan penelitian-penelitian lanjutan yang dapat mempengaruhi kinerja karyawan seperti gaya kepemimpinan, kompensasi, jenjang karir dan sebagainya, mengingat ada faktor lain yang masih mempengaruhi kinerja pegawai.

\section{DAFTAR PUSTAKA}

Arikunto, Suharmisi. 2002. Prosedur Penelitian Suatu Pendekatan Praktik. Edisi Revisi V. Jakarta: PT.Rineka Cipta.

Dessler, Gary. 2010. Manajemen Sumber Daya Manusia, Edisi kesepuluh. Indeks.

Hasibuan, Malayu. 2007. Manajemen Sumber Daya Manusia. Bumi Aksara, Jakarta.

Handoko, Hani, T. 2008. Manajemen Personalia dan Sumber Daya Manusia. BPFE, Yogyakarta.

Mathis, Robert, L, dan Jackson, Jho. 2006. Manajemen Sumber Daya Manusia. Salemba Empat, Jakarta.

Mondy, R. Wayne. 2005. Manajemen Sumber Daya Manusia, Edisi kesepuluh. Erlangga: Indonesia.

Saputra, Wiwin. 2010. Analisa Job Discription Terhadap Kinerja Karyaawan pada Sekretariat Dewan Perwakilan Rakyat Daerah Kabupaten Indragiri Hilir. Universitas Islam Indragiri, Tembilahan. 
Sarwono, Jonathan. 2006. Analisis

Data Penelitian. SPSS.

Yogyakarta.

Simanjuntak, P.J. 2005. Pengantar Manajemen Sumber Daya Manusia. Jakarta: Lembaga penerbit Fakultas Ekonomi Universitas Indonesia. 